\title{
Making global connections: the knowledge, understanding and motivation of trainee teachers
}

\author{
Cathie Holden and David Hicks
}

\begin{abstract}
This article begins by noting some of the global concerns that young people have today and highlights the crucial role of global education in responding to such concerns. It then considers the importance of teacher training in such matters and reports on a preliminary study relating to the initial training of teachers in England. In particular this raises questions about the knowledge and understanding that such students bring to their courses. It concludes by identifying some of the consequent dilemmas faced by teacher trainers working in this context.
\end{abstract}

\section{Introduction}

\section{Global concerns}

What is it that teachers need to know if they are to help pupils make sense of the world in the early twenty-first century? Long standing global issues - those to do with poverty, environment, conflict and social justice - constantly take on new forms, whether in relation to the 'war against terrorism' or the complexities of climate change and globalisation. All of these issues have a major impact on the society that students will live in, both now and in the future (Worldwatch Institute, 2003, 2004).

One useful source of information relating to young people's global concerns comes from research into their hopes and fears for the future. A study of primary aged children in the UK by Hicks and Holden (1995) showed that their main global concerns related to issues of: war and peace, pollution of the environment, food and poverty, and relationships between countries. At secondary level a high proportion of Swedish teenagers were found to take a pessimistic view of the global future, especially in relation to the environment and warfare (Oscarsson, 1996). Australian teenagers reported considerable concern about wealth and poverty, war and peace, technological change and environmental damage (Hutchinson, 1996).

Such issues were mirrored in a MORI poll (1998) in the UK where over a thousand 11-16 year olds were questioned about their knowledge of global issues. Pupils were asked what they knew about the reasons for: war in the world, destruction of the environment, famine, overpopulation, human rights abuse, and economic problems in developing countries. They were asked which of these they would like to know more about and how important they thought it was to be taught about such issues at school.

Shown a list of seven global...issues, most pupils say they know something about each. Nonetheless, in all cases a notable minority either say they know nothing or that they do not understand the topic under discussion. Reasons for war in the world is the issue that most young people are inclined to say they know something about $(72 \%)$, while at least three in five say they have some understanding of what causes environmental destruction (66\%), famine (64\%), overpopulation (63\%)...Slightly 
fewer believe they have some insight into the reasons for human rights abuse $(56 \%)$ and the economic problems of developing countries (51\%) (MORI, 1998: 4).

Television was cited as their main source of information about global issues with school, newspapers and parents following close behind. Although some pupils said they learnt about such issues at school, three-quarters wanted to know more and felt they needed such understanding to help them in the future. Over half felt that environmental disasters, war and the increasing gap between rich and poor, would seriously affect them in their adult lives. They did not, however, feel they could do much that would help to change the world.

Global concern amongst the post-secondary age group has also been tracked by educators and many of the issues referred to by these respondents are the same as those for school pupils (Gidley and Inayatullah, 2002). A typical study is that by Eckersley (1999) involving 15-24 year olds youth in Australia. He writes:

...most young people see the future in terms of a continuation or worsening of today's global and national problems and difficulties ... Major concerns included: pollution and environmental destruction, including the impact of growing populations; the gulf between rich and poor; high unemployment, including the effect of automation and immigration; conflict, crime and alienation ...discrimination and prejudice; and economic problems, including the level of foreign debt (Eckersley, 1999: 77).

A number of educational fields have responded to these concerns from global education and futures education to peace education and citizenship (Goldstein and Selby, 2000).

\section{Educational responses}

Tye's (1999) international survey exploring the nature of global education revealed a wide variety of responses from educators in some fifty countries. Nearly half of the respondents agreed in whole or part with his definition:

Global education involves learning about those problems and issues which cut across national boundaries and about the interconnectedness of systems - cultural, ecological, economic, political, and technological. Global education also involves learning to understand and appreciate our neighbours with different cultural backgrounds from ours; to see the world through the eyes of others; and to realise that other people of the world need and want much the same things (Tye, 1999: 17).

However, this survey revealed only a small number of teacher training courses anywhere in the world that attempted to promote global education.

Amongst the most progressive are a number of those in the United States which, in part, flourish as a result of the decentralised nature of the education system (Merryfield et al. 1997). The nature of pre-service teacher training here also makes it possible to infuse some courses with a global perspective, e.g. at the University of Kentucky (Wilson, 1997) in a way that may not be possible in some other countries. A number of seminal initiatives in global education have been developed in North America, such as those from the Association for Supervision and Curriculum Development (ASCD, 1990), the American Forum for Global Education (www.globaled.org) and the International Institute for Global Education (www.oise.utoronto.ca). Pike (2000) notes interesting similarities and differences between 
US, Canadian and UK approaches to global education. Whilst American educators tend to focus on reformist goals which do not call for the reshaping of the world, Canadian and UK educators tend to highlight differences in relation to wealth, power and rights.

\section{The UK context}

A concern that education in the UK should help young people become more world-minded dates back to progressive teachers in the 1920s and later work in the post-war years (Heater, 1980). During the 1970s the World Studies Project worked with secondary teachers and teacher trainers to be succeeded in the 80s by the World Studies 8-13 Project (Hicks, 1990) which worked with primary teachers in half of the Local Education Authorities in England and Wales. Also influential at this time was the work of Pike and Selby $(1988,1995)$ with numerous secondary schools. Their work continues to influence models of global education in the UK today (Hicks, 2003).

More recently in the UK educational interest in a global perspective has been quickened by the emergence of citizenship, race equality and sustainability as key areas of concern in the English national curriculum. Citizenship, for example, requires that pupils learn about "the world as a global community, and the political, economic, environmental and social implications of this" (DfEE, 1999: 14). The Parekh Report (2000: 23) on the future of multiethnic Britain argues that "British national identity has always been more diverse than it is normally imagined to be" and cites globalisation as one of the main sources of social and cultural change. At the Earth Summit in 1992 it was recognised that issues of environment and development were fundamentally interconnected and, as education for sustainable development, this is now a key element in the curriculum in England (www.ofsted.gov.uk).

Of particular recent importance has been the growth in official support for 'global education' as witnessed by Putting the World into World-Class Education (DfES, 2004)), Developing a Global Dimension in the School Curriculum (DfES, 2005) and Education for Sustainable Development and Global Citizenship in Wales (ACCAC, 2002). The first two documents argue the need for students to understand the following eight key concepts: citizenship, social justice, sustainable development, diversity, values and perceptions, interdependence, conflict resolution, human rights. Significant support also comes from non-governmental organisations (NGOs) such as Oxfam (1997) which espouses the need for 'global citizenship' in schools and the Department for International Development (www.dfid.gov.uk) is currently making grants available to support schools and NGOs in developing a global dimension in the curriculum.

\section{Initial teacher education in England *}

Initial Teacher Education and Training (ITET) in England has very specific parameters, as the training that student teachers (or 'trainees' as they are known) receive is tightly controlled by the Teacher Training Agency (TTA). This government body decides the standards against which all trainees must be assessed in order to achieve Qualified Teacher Status (QTS) and the requirements against which all ITET providers are evaluated. Most students receive their training in university schools of education where those wishing to teach in secondary schools (age 11-18) follow a one-year Post Graduate Certificate in Education (PGCE) course of which twelve weeks is in the university and twenty four in school. For those wishing to teach in primary schools (age 4-11) approximately 40 per cent follow an undergraduate course of three 
or four years leading to a degree with QTS whilst the other 60 per cent take a one year PGCE, of which twenty weeks will be in the university and eighteen in school.

Because of the short time spent in the university and the requirements of the TTA, university courses tend to focus on the acquisition of national curriculum subject matter knowledge and on the basics of planning, assessment and management in the classroom. A particular emphasis is placed on the core subjects of English, mathematics and science. Secondary trainees focus on learning to teach their national curriculum subject and are unlikely to cover global issues unless they are geography or citizenship students; primary students are similarly unlikely to find such a global focus on their short and tightly defined courses.

Students in England coming to pre-service training are likely to have in-depth knowledge on a relatively narrow range of topics, unlike their counterparts in some other countries. A typical entrant to an undergraduate programme will have focussed on only three or four areas of study in their last two years at school and will have three A-levels in national curriculum subjects such as history, English, science or geography. A typical post-graduate student will have a degree which is usually single-subject focused. Few degree courses are as modularised as in North America or Australia with the result that trainees begin their training with variable or little knowledge of global issues, global history or world cultures.

This lack of formal education about global issues and the lack of time on ITET programmes to focus on this area underlines the importance of research into student teachers' knowledge, understanding and motivation if we are to have a new generation of teachers able and willing to address the concerns of young people about world issues and events.

* In the context of the research described here we refer only to training in England as requirements in Wales, Scotland and Northern Ireland differ.

\section{The research}

The purposes of this study were to investigate further the knowledge and understanding that trainee teachers have of global issues and their motivation to include a global dimension in their teaching. In particular we wished to find out:

- How knowledgeable trainee teachers feel they are about various global issues

- What appear to be the influences on their global knowledge and understanding

- What prior experience of global issues/matters trainees arrive with

- To what extent trainees feel motivated to teach about global issues

This paper reports on the findings from this research and discusses some of the main implications for ITET in England.

\section{Methodology}

Both quantitative and qualitative methods of data collection were used, the former in order to obtain responses from a large number of trainees and the latter to enable more in-depth exploration of student understanding. Trainee teachers from four universities across the southwest of England were recruited to provide data for three samples which reflect the training routes taken by most prospective teachers: 
- Cohort 1:313 primary PGCE trainees

- Cohort 2: 442 secondary PGCE trainees

- Cohort 3: 101 primary undergraduate trainees [Total 856]

The sample was thus divided more or less equally between secondary and primary trainees. The secondary students were being trained to teach a national curriculum subject which was based on their degree (e.g. English, maths, history, science, physical education). The exception was the group training to be secondary citizenship teachers, a new national curriculum subject, where their degrees came from related fields such as politics, law, sociology. Primary students were being trained to teach all subjects of the national curriculum, with an emphasis on English, maths and science. Half of the total sample was in the 18-23 age range, with 35 per cent in the 24-34 age range and 15 per cent over 35 . Threequarters of the sample were female, with the majority of the men being secondary trainees. The undergraduate students were in their first year at university.

Quantitative data were obtained through the use of a questionnaire given to all 856 students. The questionnaire was based on that used by MORI (1998 op cit) to investigate pupils' knowledge of global issues so that some comparisons could be made between the responses of pupils and trainee students in relation to their respective knowledge of and interest in such issues. When pupils were asked about their knowledge they had been given three choices from 'know something', 'know nothing' and 'don't know'. As it was felt that trainees would be better informed the questionnaire allowed a choice between 'know a lot', 'know something' and 'know nothing'. Further questions were added to elicit information about trainees' prior experience as it was felt that this could have a bearing on their knowledge and understanding. The data was analysed quantitatively using Sphinxsurvey Plus2 which allowed for cross-referencing (www.sphinxdevelopment.co.uk). Raw numbers were analysed using chi-squared but percentages are reported in the tables.

Qualitative data were obtained from in-depth interviews. A total of 216 students volunteered to be interviewed, from which a sample of 41 was selected. This sample reflected the balance of the three cohorts: 11 male and 30 female, 32 PGCE and 9 undergraduates, 23 primary and 18 secondary. The interviews, carried out in small groups, were semi-structured and tape recorded. The themes in the questionnaire formed the basis for the interview, with the interviewer asking trainees to 'say more about' particular questions as well as discussing their interest in teaching about global issues and their perceptions of their training. Interviews were analysed using constant comparative technique (Wellington, 2000)

\section{Findings from the questionnaires}

The findings from the quantitative data give an overview of student' perceptions and indicate significant statistical differences between responses from undergraduates and postgraduates, secondary and primary trainees. All figures have been rounded to the nearest percentage point.

a) Trainees' knowledge of global issues

\begin{tabular}{|l|c|c|c|}
\hline Knowledge of global issues & $\begin{array}{c}\text { Know a } \\
\text { lot }\end{array}$ & $\begin{array}{c}\text { Know some- } \\
\text { thing }\end{array}$ & Know nothing \\
\hline Reasons for war in the world & $17 \%$ & $81 \%$ & $2 \%$ \\
\hline
\end{tabular}




\begin{tabular}{|l|c|c|c|}
\hline Reasons for famine in the world & $17 \%$ & $79 \%$ & $4 \%$ \\
\hline Reasons for environmental problems & $20 \%$ & $74 \%$ & $6 \%$ \\
\hline Reasons for overpopulation & $20 \%$ & $74 \%$ & $6 \%$ \\
\hline $\begin{array}{l}\text { Reasons for the Third World's } \\
\text { economic problems }\end{array}$ & $15 \%$ & $74 \%$ & $11 \%$ \\
\hline Reasons for human rights abuses & $11 \%$ & $75 \%$ & $14 \%$ \\
\hline
\end{tabular}

Table 1: Knowledge of global issues $(n=856)$

The majority of trainees claim that they either know 'something' or 'a lot' about most of today's global problems. They appear to know most about the reasons for war and famine and least about the reasons for economic problems in the third world and for human rights abuses.

In order to ascertain if levels of knowledge and understanding were evenly distributed across the three sample groups, further analyses of the responses to 'reasons for war' and 'reasons for environmental problems' were carried out. These two issues were selected as teaching about environmental matters in the UK has an established history whereas teaching about the reasons for war does not. Cross-referencing of the responses by cohort revealed statistically significant differences:

\begin{tabular}{|l|c|c|c|c|}
\hline War & $\begin{array}{c}\text { PGCE } \\
\text { primary }\end{array}$ & $\begin{array}{c}\text { PGCE } \\
\text { secondary }\end{array}$ & $\begin{array}{c}\text { Under } \\
\text { graduate }\end{array}$ & TOTAL \\
\hline I know a lot about this & $11 \%$ & $24 \%$ & $5 \%$ & $\mathbf{1 7 \%}$ \\
\hline I know something about this & $86 \%$ & $75 \%$ & $91 \%$ & $\mathbf{8 1 \%}$ \\
\hline I know nothing about this & $3 \%$ & $1 \%$ & $4 \%$ & $\mathbf{2 \%}$ \\
\hline TOTAL & $\mathbf{1 0 0 \%}$ & $\mathbf{1 0 0} \%$ & $\mathbf{1 0 0 \%}$ & $\mathbf{1 0 0 \%}$ \\
\hline
\end{tabular}

Table 2: Knowledge of reasons for war by (by cohort) $(n=856)$

\begin{tabular}{|l|c|c|c|c|}
\hline Environmental problems & $\begin{array}{c}\text { PGCE } \\
\text { primary }\end{array}$ & $\begin{array}{c}\text { PGCE } \\
\text { secondary }\end{array}$ & $\begin{array}{c}\text { Under } \\
\text { graduate }\end{array}$ & TOTAL \\
\hline I know a lot about this & $17 \%$ & $24 \%$ & $10 \%$ & $\mathbf{2 0 \%}$ \\
\hline I know something about this & $77 \%$ & $78 \%$ & $79 \%$ & $\mathbf{7 4 \%}$ \\
\hline I know nothing about this & $6 \%$ & $4 \%$ & $\mathbf{1 1 \%}$ & $\mathbf{6 \%}$ \\
\hline TOTAL & $\mathbf{1 0 0 \%}$ & $\mathbf{1 0 0} \%$ & $\mathbf{1 0 0} \%$ & $\mathbf{1 0 0 \%}$ \\
\hline
\end{tabular}

Table 3: Knowledge of reasons for environmental problems (by cohort) ( $\mathrm{n}=856)$

These findings indicate that students' perceived levels of knowledge vary according to the age they are training to teach and whether they are undergraduates or postgraduates. Figures in italics indicate statistically significant difference. Thus the majority of the first year undergraduates claim to 'know something' about the reasons for global environmental problems, but they are much less likely than their PGCE counterparts to 'know a lot' and just over one in ten claims to 'know nothing'. Secondary PGCE trainees are the most confident in their knowledge of both the reasons for war and environmental problems. The numbers claiming to 'know a lot' is statistically significant. Further analysis indicates that the student's subject specialism may be important. Nearly half of secondary history and citizenship students say they know a lot about reasons for war (compared with 17 per cent of 
trainees overall), and when asked about the reasons for environmental problems, citizenship, geography and science students are most likely to say they know a lot about these $(41,39$ and 32 per cent respectively, compared to 20 per cent overall).

\section{b) Sources of information}

\begin{tabular}{|l|c|c|c|c|}
\hline Sources of information & $\begin{array}{c}\text { PGCE } \\
\text { primary }\end{array}$ & $\begin{array}{c}\text { PGCE } \\
\text { secondary }\end{array}$ & $\begin{array}{c}\text { Under } \\
\text { graduate }\end{array}$ & TOTAL \\
\hline Television & $94 \%$ & $96 \%$ & $97 \%$ & $\mathbf{9 5 \%}$ \\
\hline Newspapers & $90 \%$ & $92 \%$ & $86 \%$ & $\mathbf{9 0 \%}$ \\
\hline Friends & $65 \%$ & $60 \%$ & $37 \%$ & $\mathbf{5 9 \%}$ \\
\hline Family & $58 \%$ & $52 \%$ & $58 \%$ & $\mathbf{5 5 \%}$ \\
\hline Internet & $47 \%$ & $58 \%$ & $47 \%$ & $\mathbf{5 3 \%}$ \\
\hline University & $48 \%$ & $48 \%$ & $11 \%$ & $\mathbf{4 4 \%}$ \\
\hline School & $30 \%$ & $35 \%$ & $47 \%$ & $\mathbf{3 4 \%}$ \\
\hline
\end{tabular}

Table 4: Sources of information about global issues (by cohort) $(n=856)$

(NB. Responses total more than $100 \%$ as students could tick more than one source)

It is interesting that the majority of students feel that they get most their information on global issues from the media (television and newspapers) rather than from school or university. This is true for students on all three training routes and raises further questions about the nature of this claimed knowledge, their interest and efficacy. Undergraduates appear less likely to look to their peers as sources of information and more likely to cite their work in school than postgraduates. They are understandably less likely to refer to university as a source of information as this group are only in the first year of their degree.

\section{c) Prior experience}

Questions on prior experience of global issues as well as exposure to cultures other than their own were included in the study as it seemed likely this would be a significant factor in determining both trainees' knowledge and their motivation to teach about global issues.

\begin{tabular}{|l|c|c|c|c|}
\hline Prior experience of global issues & $\begin{array}{c}\text { PGCE } \\
\text { primary }\end{array}$ & $\begin{array}{c}\text { PGCE } \\
\text { secondary }\end{array}$ & $\begin{array}{c}\text { Under } \\
\text { graduate }\end{array}$ & TOTAL \\
\hline Have lived and worked abroad & $45 \%$ & $45 \%$ & $5 \%$ & $\mathbf{4 0 \%}$ \\
\hline $\begin{array}{l}\text { Have family/friends from other } \\
\text { cultural backgrounds }\end{array}$ & $64 \%$ & $56 \%$ & $28 \%$ & $\mathbf{5 5 \%}$ \\
\hline $\begin{array}{l}\text { Am particularly interested in global } \\
\text { issues }\end{array}$ & $59 \%$ & $58 \%$ & $17 \%$ & $\mathbf{5 3 \%}$ \\
\hline Not applicable & $11 \%$ & $12 \%$ & $59 \%$ & $\mathbf{1 8 \%}$ \\
\hline
\end{tabular}

Table 5: Experience of and interest in global issues (by cohort) $(\mathrm{n}=856)$

(NB. Responses total more than $100 \%$ as students could tick more than one response) 
Overall, a considerable number of trainees (40\%) have lived or worked abroad and over half have friends or family from cultures other than their own or are interested in global issues. However a sizeable minority - nearly one fifth - have no particular interest in global issues and no connections with other places or peoples.

Analysis by cohort indicates that it is PGCE students who are most likely to have lived or worked abroad and that there is a direct correlation between this and their interest in global issues. Both primary and secondary PGCEs appear to have had the same level of experience abroad and claim the same level of interest, but secondary students claim greater knowledge (Tables 2 and 3). This greater confidence amongst secondary students may warrant further research. Does this relate to gender (the majority of men were secondary students) or are secondary trainees generally more knowledgeable about world issues? Also of note is the statistically significant number of undergraduates saying these areas are 'not applicable': well over half claim to have no particular interest in global issues and no experience of other cultures or countries. This correlates with their expressed lack of knowledge on such issues. This raises a vital question for undergraduate programmes: if a knowledge and understanding of global issues is important to prospective teachers there may need to be a broadening of the experiences, both direct and mediated, that undergraduates have.

\section{d) Trainees' motivation as teachers of global issues}

The above findings refer to trainees' claimed knowledge and experience. In order to understand their motivation as learners, they were asked to indicate which of the following global issues they would like to know more about.

\begin{tabular}{|l|c|}
\hline More knowledge of global issues & TOTAL \\
\hline Reasons for human rights abuses & $\mathbf{7 4 \%}$ \\
\hline Reasons for war in the world & $\mathbf{6 9 \%}$ \\
\hline $\begin{array}{l}\text { Reasons for the Third World's } \\
\text { economic problems }\end{array}$ & $\mathbf{6 5 \%}$ \\
\hline Reasons for famine in the world & $\mathbf{6 3 \%}$ \\
\hline Reasons for environmental problems & $\mathbf{6 1 \%}$ \\
\hline Reasons for overpopulation & $\mathbf{5 4 \%}$ \\
\hline
\end{tabular}

Table 6: Desire for more knowledge of global issues $(n=856)$

(NB. Responses total more than $100 \%$ as students could tick more than one response)

This table shows a strong desire on the part of most students to know more about global issues. A comparison with Table 1 indicates that trainees felt least confident in their knowledge of reasons for human rights abuses, and this appears here as the area they most wish to know more about. Whilst knowledge of the reasons for war came first in Table 1, the fact that over two thirds of trainees still wish to have more knowledge of this area may signify its importance to them.

In a final question students were asked whether they felt they could make a difference to pupils' understanding of global issues when they became teachers. Over half of the trainees 'strongly agreed' that they could make a difference to pupils' understanding, with a further 40 
per cent 'tending to agree'. PGCE trainees were more likely to feel they could make a difference than the undergraduates who, having less experience of these issues, were more ambivalent in their response.

Taking these last two questions together, it would appear that the majority of trainees are both motivated to learn more about global issues themselves and feel that they can make a difference to pupils' understanding of these issues. What is not clear is the extent to which they feel confident and prepared to teach about such issues in the classroom. It was hoped that the in depth interviews would provide some answers.

\section{Comparison with the MORI data}

The questionnaire was partly designed to reflect the MORI poll (1998) which mapped over a thousand 11-16 year olds' knowledge of global issues. Comparison indicates that while trainees (and particularly postgraduates) know more, both pupils and trainees feel most confident in their knowledge of reasons for war and least confident in their knowledge of human rights abuses. A notable minority of both undergraduates and pupils know nothing (or do not understand) about the topics under discussion.

Both pupils and trainees cite television and newspapers as their primary sources of information about global issues. Other important sources for the pupils are school and parents - also mentioned by the undergraduates. Three out of five of the pupils either agree or tend to agree that they should be taught at school 'about issues affecting the world' and in a parallel question about whether global issues should be taught at school two thirds of trainees 'strongly agree' with the remaining third 'tending to agree'. A similar proportion of trainees feel they can make a difference to pupils' understanding of such issues. There appears to be much common ground between the groups: both feel global issues are important, that they should be part of the curriculum and both seem motivated to learn more.

\section{Findings from the interviews}

It was hoped that interviews would shed more light on these statistics and add to an understanding of trainees' responses. The numbers interviewed (41 in total) are too small to enable meaningful comparisons of the subsets of students and are used here as illustrative of responses to particular questions. The students interviewed were positive about the inclusion of global perspectives in the curriculum and seemed representative of the majority who felt that such issues were important. Whilst nearly one in five of the whole sample claimed not to be particularly interested in global issues and with little prior experience of other cultures, these views were not represented in the interviews. Further research is thus needed on those who are neither interested in global issues nor in being able to teach about them.

\section{a) Prior experience}

In the interviews students who had lived and/or worked abroad were asked to say more about the nature of this and its effect on their own knowledge and understanding. A wide range of experiences was revealed. Some had taught English in other countries, e.g. India, Nepal and Morocco. Others had done voluntary work abroad, such as working for VSO, for the Raleigh International Project in Ghana and for Aids Awareness in Zimbabwe. Some had lived abroad with their families (in India, Australia, Nigeria) or travelled extensively (in Nepal, Pakistan, China, Spain). All spoke of the importance of experiencing difference. They spoke in terms of 
cultural difference, ideological difference and the difference in terms of wealth and privilege. For many their time abroad had raised issues of justice and equality and had given them greater knowledge and new insights. One student explained:

It opens up your eyes to how other people live and the problems they face and how like you they are... I feel that everyone is similar to each other... we live in different places but we're fundamentally the same.

A student who had been going to India since she was young because her father worked there, described the experience as 'forming who I am'.

Those who had not had experience of living or working abroad were asked what had helped form their opinions about global issues. Some said that though did not have this first hand experience they were nonetheless aware of and interested in global issues. Some were involved with campaigning organisations or charities in the UK, such as Amnesty, Greenpeace, Traidcraft and local environmental or action groups. Interest in and commitment to environmental and sustainability issues was high, particularly among the undergraduates. One spoke of her group of friends where a lot of emphasis was put on recycling; another said she was not 'politically active' but tried to buy eco-friendly products, dolphin friendly tuna and Fairtrade coffee.

When asked to talk more generally about influences on their thinking, many cited the importance of parents, friends or religious beliefs. Six students spoke about coming from a family 'who discusses a lot' or were politically aware. Others mentioned parents who encouraged social responsibility, re-cycling or were involved in campaigning of some sort. Seven commented on their personal values and belief systems, referring to the influence of religion (Quaker, Christian, Buddhist) or of being vegetarian. One said: 'I feel a responsibility to live a certain way (but) I don't actively tell other people about it'.

For some their first degree had made the biggest difference. Five referred specifically to their degree having made them 'better informed'. Two cited their degrees in European studies where they felt they had gained 'a broad view on different issues', whilst another talked about his degree in economics which included a global perspective. The experience of students in the workplace was also important. Many mentioned this as 'opening their eyes' and one talked of her work with a company writing an 'environmental management plan' which taught her about pollution, land use and conflicting needs.

Many wanted to point out that while they themselves were interested in global issues and committed to working for change they did not feel other students necessarily shared their concerns. A mature student commented:

I live in a flat with people who are sort of 22, they honestly just don't give a damn, they don't think about it, they're not involved with any charities, they don't give a toss about environmental concerns, they just want to go out, get pissed on Friday night and watch the footy on Saturday and have fun - there's this whole kind of Hollyoaks youth culture which wasn't (around in) my adolescence and I find that really scary.

This perception reinforces the need for further research into those trainees with no apparent interest in global issues. 


\section{b) Motivation in relation to a global perspective}

The quantitative data indicated that the majority of students wished to know more about global issues and felt they could make a difference to pupils' understanding. This was reflected in the interviews. Students said it was 'essential' that pupils learnt about such issues, that they had broad horizons, were able to 'live internationally' and could see beyond their own 'small world'. One argued that teachers who didn't think globally were 'short changing the children'. For another there was an important link between 'active citizenship and global awareness. You need to be aware of your actions... that your actions have consequences'. The enthusiasm of one student for such an approach came from a placement school where she saw that the 'whole school ethos' reflected a commitment to cultural diversity and global citizenship.

A common perception among these students was that teaching literacy and numeracy was only part of a bigger picture. Several commented that the skills of reading and writing were only important in terms of how they were used. One felt that while 'learning tables and handwriting are valid skills that you need in life...if you're not exposed to all those other issues, you're not going to be a fully formed person'. Many felt it was imperative for environmental issues to be addressed and sustainable lifestyles developed. Another felt that education was too often 'geared toward economic production' or restricted by the political regime, whereas true education was about 'freedom in your mind... it's what we should be striving for' and it was here that she saw the links to global education. What was common to all was a view that education needed to be about widening horizons and about preparing children for the challenges of life in an increasingly global society.

Whilst the majority of those interviewed were committed and enthusiastic about including global perspectives in their teaching, this was tempered by concerns about how best to teach about what seemed complex and sensitive issues. An undergraduate had been on her first school placement at the time of 9/11 in a Year 1 class. In interview she recalled:

(Pupils) came up to me and said 'Did you see what happened and how many people died?' but the teacher wouldn't discuss it. I think they should have had a moment, a few minutes just to discuss it briefly, get it off their chests, try to understand it in their own way without just going (straight) into the numeracy hour.

She felt she was not allowed to talk about what had happened with the children and was left feeling frustrated by her inability to address their needs. Another primary teacher worried about being 'vested with this huge authority as a teacher' which might, she thought, lead her to influence children without letting them make up their own minds. Concerns voiced by others through out the interviews were:

- How to deal with fear (i.e. children's reactions to war and violence)

- Knowing how to judge what is/isn't appropriate (especially with young children)

- Their own role - should they try to be neutral or give their opinion?

- The reaction of parents to teachers dealing with controversial issues

- The time to teach about global issues along with everything else that is required

- A lack of confidence in dealing with sensitive issues (e.g. Iraq, immigration)

- Knowing how to facilitate meaningful discussion

- Having sufficient knowledge themselves on current issues 
While the findings from the questionnaires indicated a desire to know more about global issues and a belief in their ability to help children understand such topics, the concerns raised in the interviews revealed some of the barriers to effective delivery in the classroom. Trainees felt they needed more guidance and more knowledge themselves if they were to feel competent to teach about global issues.

\section{Summary of data}

Data from the questionnaires indicate that many trainee teachers appear well motivated to teach about global issues and confident in their own knowledge, with the majority 'knowing something' about the issues under discussion. However, further analysis indicates that there are considerable differences in levels of assumed knowledge and motivation between the three samples. Secondary trainees are more confident in their knowledge than their primary counterparts, whilst primary undergraduates are the least confident group. The subject specialism of secondary students is significant in terms of their knowledge and motivation.

Sources of information are primarily TV and newspapers, followed by friends, family and the internet. Prior experience (living/working abroad) and contact with other cultures appear to directly influence trainees' interest in and knowledge of global matters. The undergraduate students who have the least experience of other cultures and who are least likely to have lived or worked abroad, are much less motivated to teach about global issues.

The interviews endorse the wealth of prior experience brought by many to their PGCE courses and reflect their level of commitment to global issues. They indicate that even though many express doubts about some elements of their own knowledge, they nonetheless feel committed to addressing young people's concerns about these issues. The interviews also shed light on the reasons for many trainees' expressed lack of confidence: global issues are seen as sensitive, controversial and complex and they feel they need specific guidance on appropriate teaching methods and better subject knowledge.

\section{Discussion}

Whilst in some ways the overall findings of this study could, in an international context, be seen as unsurprising they are nevertheless important because they relate to a hitherto largely unresearched situation - that of ITET in England. One of the few analyses of a DfID funded project for trainee teachers in the UK (Robbins et al. 2003) echoes our own findings. This project at the University of Wales, Bangor, was concerned with embedding education for global citizenship into pre-service teacher education courses. Such courses they argue:

...have a key role in equipping teachers with the necessary competence to contribute effectively to cross-curricular and whole-school approaches which promote progress towards concern and action for equal opportunities, social justice and sustainable development from the local to the global scale (Robbins et al. 2003:.94).

At the end of their course 76 per cent of the secondary trainee teachers and 59 per cent of the primary trainees felt that global citizenship should have a high priority in the curriculum. However only just over a third felt confident that they could contribute to a whole school approach to this in school. It was also shown that there were significant differences in attitude depending on trainees' main subject. 
There are several key issues here for those who work in ITET to address. Quite clearly more detailed research is needed in the UK context into the impact of prior cross-cultural experiences on students' attitudes. Thomas (2001), for example, found that teachers with experience of VSO (Voluntary service Overseas) were more committed to introducing global perspectives into their teaching. The impact of this and similar experiences on teacher attitudes has been well documented by Merryfield (1997), Beijaard, Meijer and Verloop (2004) and others. The increasing popularity of 'gap' years and the culturally diverse nature of British society mean that many students do arrive at university with knowledge and experience of cultures and countries other than their own. Tutors need to be more cognisant of and build upon such experiences in ITET. Using new teachers' experiences of and commitment to global issues could be one way into a broader curriculum and more relevant and innovative teaching.

Unlike the situation in North America where students may have studied a number of courses with a specific global component their counterparts in the UK may be less likely to have had this opportunity. That things are beginning to change however is borne out by a recent report on Global Perspectives in Higher Education (Development Education Association, 2003). This offers insights into what a global perspective might look like in a number of undergraduate (and post-graduate) modules such as Global Citizenship and Civic Society, Globalisation and Ethics in the Workplace and Global Responsibility and Sustainable Business Practice. These case studies provide details of how such modules have been developed and the ways in which they engage students with complex global issues. Should such students then wish to train as teachers they would then come with considerable global insight. At some universities students can take a degree in Education Studies, which may contain a global component, before applying for PGCE (Ward, 2004).

Quite clearly the findings from this preliminary survey also raise questions about the nature of pre-service courses themselves. As indicated earlier in this article there are both strong governmental and time restraints on what is possible in ITET courses. Nevertheless, a number of global educators in the UK have been working to find ways of helping their trainee teachers become more knowledgeable about the state of the world. A range of innovative case studies is examined in Global Perspectives and Teachers in Training (Development Education Association, 2004). These include examples of embedding global citizenship and sustainable development in a BEd degree course, introducing a global dimension through citizenship, using school gardens in relation to sustainability and citizenship, educational study trips to south India, and integrating global perspectives into Business and Economics Education PGCE. It is important to note that several of the initiatives described above have been supported by grants from the Department for International Development (www.dfid.gov.uk).

It is vital that ITET programmes find ways of broadening their remit. There needs to be time and provision for students to learn strategies for teaching about global and controversial issues, time for them to improve their own knowledge and understanding, and time for them to learn how to critically evaluate sources of information. Garratt and Piper (2003: 143) accordingly highlight the need to challenge "the limitation of a classroom competency driven approach to teacher training in comparison with a more socially conscious conception of teacher education." The world of the early twenty-first century is complex and fast changing. Local and national issues, events and trends can only be understood if set in the wider global context. As this paper has highlighted, global education has a crucial role to play in ensuring that efforts by the UK government to promote a global dimension in the curriculum are more 
than lip service. Its effective delivery in schools will largely depend on the understanding, ability and motivation of student teachers to help young people make such 'global connections'.

\section{References}

ACCAC (2002) Education for Sustainable Development and Global Citizenship,

Birmingham: Qualifications, Curriculum and Assessment Authority for Wales

American Forum for Global Education, www.globaled.org (accessed 24.1.05)

Association for Supervision and Curriculum Development (1990) Global Education: From

Thought to Action, Alexandria, VA: ASCD

Beijaard, D., Meijer, P., Verloop, N. (2004) Reconsidering research on teachers' professional identity, Teaching and Teacher Education, 20 (2) 107-128.

Department for Education and Employment, (1999) The National Curriculum, London:

DfEE.

Department for Education and Employment (1999) Citizenship: Key Stages 3-4, London:

DfEE

Department for Education and Skills (2005) Developing a Global Dimension in the School Curriculum, London: DfES Publications

Department for Education and Skills (2004) Putting the World into World-Class Education, London: DfES Publications

Department for International Development, www.dfid.gov.uk (24.1.05)

Development Education Association (2003) Global Perspectives in Higher Education, London: DEA

Development Education Association (2004) Global Perspectives and Teachers in Training, London: DEA

Education for sustainable development, www.ofsted.gov.uk (24.1.05)

Eckersley, R. (1999) Dreams and expectations: young people's expected and preferred futures and their significance for education, Futures, 31 (1): 73-90

Garratt, D. and Piper, H. (2003) Citizenship education and the monarchy: examining the contradictions, British Journal of Educational Studies, 51 (2): 127-147.

Gidley, J. and Inayatullah, S. (2002) Youth Futures, Westport CT: Praeger

Goldstein, T. and Selby, D. (2000) Weaving Connections: Education for Peace, Social and Environmental Justice, Toronto: Sumach Press

Heater, D. (1980) World Studies: Education for International Understanding, London: Harrap

Hicks, D. (2003) Thirty years of global education: a reminder of key principles and practice, Educational Review, 55 (3): 265-75

Hicks, D. (1990) World Studies 8-13: a short history 1980-89, Westminster Studies in Education, 13: 61-80

Hicks, D. \& Holden, C. (1995) Visions of the Future: Why we Need to Teach for Tomorrow, Stoke-on-Trent: Trentham Books

Hutchinson, F. (1996) Educating Beyond Violent Futures, London: Routledge

International Institute for Global Education www.oise.toronto.ca (accessed 24.1 05)

Merryfield, M., Jarchow, E. and Pickert, S. eds. (1997) Preparing Teachers to Teach Global Perspectives: Handbook for Teacher Educators, Thousand Oaks, CA: Corwin Press.

MORI (1998) Children's Knowledge of Global Issues, London: MORI

Oscarsson, V. (1996) Young people's views of the future, in A. Osler, H-F, Rathenow and H. Starkey, eds. Teaching for Citizenship in Europe, Stoke-on-Trent: Trentham Books

Oxfam (1997) A Curriculum for Global Citizenship, Oxford: Oxfam Development Education Programme 
Parekh Report (2000) The Future of Multi-ethnic Britain, London: Profile Books

Pike, G. (2000) Global education and national identity: in pursuit of meaning, Theory into Practice, 39 (2): 64-74

Pike, G. and Selby, D. (1988) Global Teacher, Global Learner, London: Hodder and Stoughton

Pike, G. and Selby, D. (1995) Reconnecting: From National to Global Curriculum,

Godalming: World Wide Fund for Nature UK

Robbins, M., Francis, L. and Elliott, E, (2003) Attitudes towards education for global citizenship among trainee teachers, Research in Education, 69: 93-98

Thomas, G. (2001) Human Traffic: skills, employers and international volunteering, London: Demos.

Tye, K. (1999) Global Education: A Worldwide Movement, Orange, CA: Independence Press Ward, S. (ed) (2004) Education Studies: A Student's Guide, London: RoutledgeFalmer Wellington, J (2000) Educational Research: Contemporary Issues and Practical Approaches, London: Continuum.

Wilson, A. (1997) Infusing global perspectives throughout a secondary social studies program, in Merryfield, M. et al. (ibid)

Worldwatch Institute (2003) Vital Signs 2003-04, London: Earthscan

Worldwatch Institute (2004) State of the World 2004, London: Earthscan

www.sphinxdevelopment.co.uk

NB. Our thanks to Fran Martin and Nick Clough for their comments on this paper. 